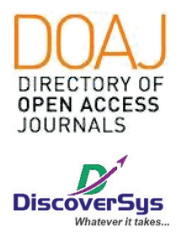

Published by DiscoverSys

\section{Gambaran riwayat kejadian diare pada balita dan pelaksanaan PHBS dalam tatanan rumah tangga di Desa Gegelang Kecamatan Manggis tahun 2013}

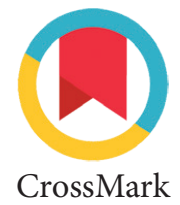

Dewa Agung Istri Sintha Prajnyaswari, ${ }^{1 *}$ Wayan Citra Wulan Sucipta Putri ${ }^{2}$

\section{ABSTRACT}

Background: Diarrhea is the second leading cause of death in infants. As one of the disease-based environment, the availability of clean water, sanitation and hygiene is one of the key actors in the incidence of diarrhea. As one of the efforts to improve sanitation and hygiene, health center movement Manggis I community health center develops behaviors of live clean and healthy (PHBS) at the family level. The lowest percentage of households classified by PHBS located in the Gegelang Village which amount is $46 \%$. Among the 10 points PHBS, the cause of diarrhea in infants can be sourced history of exclusive breastfeeding, use of unclean water, the habit of not washing hands with soap and clean water, and does not have healthy latrines.

Methods: This study was a descriptive cross-sectional study involving seventy-five respondents, i.e. mothers with under five children (12-60 months) in Hamlet Gegelang, Kalanganyar, and Pakel, Gegelang
Village. Sampling technique is done by using accidental sampling method. Data collection was conducted using a questionnaire. In this research is found only 13 of 75 (17.3\%) of respondents said that the children did not have diarrhea in the last 1 year.

Results: A total of 53 respondents (70.7\%) said that they did not give exclusive breastfeeding to her child. All respondents had access to clean water, but only 32 of 75 (42.7\%) of respondents who process a clean water with appropriate way before drunk. Good hand washing habits only depicted in 30 of 75 (40\%) of respondents. Latrine ownership were vary from having latrine with standards compliant (38.7\%), have latrine but do not fit to standards-compliant (25.3\%), and did not have latrine (36.0\%).

Conclusion: Cross-tabulations showed a trend increase in the number history of diarrhea in under five children on the implementation of PHBS that do not fit to health standards.

Keywords: diarrhea, under-five children, PHBS, Manggis I Public Health Care

Cite This Article: Prajnyaswari, D.A.I.S., Putri, W.C.W.S. 2018. Gambaran riwayat kejadian diare pada balita dan pelaksanaan PHBS dalam tatanan rumah tangga di Desa Gegelang Kecamatan Manggis tahun 2013. Intisari Sains Medis 9(1): 10-18. D0I: 10.1556/ism.v9i1.147

Latar Belakang: Diare merupakan penyebab kematian terbesar kedua pada balita. Sebagai salah satu penyakit berbasis lingkungan, ketersediaan air bersih, sanitasi dan higenitas adalah salah satu pemegang peranan penting pada kejadian diare. Sebagai salah satu upaya peningkatan sanitasi dan higenitas, puskesmas Manggis I melakukan gerakan perilaku hidup bersih dan sehat (PHBS) di tingkat keluarga. Persentase terendah rumah tangga yang diklasifikasikan sehat berdasarkan PHBS di wilayah kerja Puskesmas Manggis I terletak di Desa Gegelang yaitu sebesar 46\%. Diantara 10 poin PHBS, penyebab diare pada balita dapat bersumber riwayat pemberian ASI eksklusif, penggunaan air yang tidak bersih, kebiasaan tidak mencuci tangan dengan air bersih dan sabun, serta tidak memiliki jamban yang sehat.

Metode: Penelitian ini merupakan studi deskriptif cross sectional dengan melibatkan tujuh puluh lima responden yakni ibu yang memiliki balita 12-60 bulan di Dusun Gegelang, Kalanganyar, dan
Pakel di Desa Gegelang Teknik pengambilan sampel dilakukan dengan metode accidental sampling. Pengumpulan data dilakukan menggunakan kuesioner. Pada penelitian ini didapatkan hasil hanya 13 dari 75 (17,3\%) responden mengatakan bahwa anaknya tidak pernah mengalami diare dalam 1 tahun terakhir.

Hasil:Sebanyak 53 responden (70,7\%) menyatakan tidak memberikan ASI eksklusif pada anaknya. Seluruh responden memiliki akses air bersih, tetapi hanya 32 dari 75 (42,7\%) responden yang memenuhi mengolah air bersih secara benar sebelum dikonsumsi. Kebiasaan cuci tangan yang baik dan benar hanya tergambar pada 30 dari 75 (40\%) responden. Kepemilikan jamban bervariasi mulai dari memiliki dan sesuai standar (38,7\%), memiliki tetapi tidak sesuai standar (25,3\%), dan tidak memiliki jamban (36,0\%).

Simpulan: Hasil tabulasi silang menunjukkan kecenderungan peningkatan jumlah riwayat kejadian diare pada balita terhadap pelaksanaan PHBS yang tidak sesuai dengan standar kesehatan. 


\section{PENDAHULUAN}

Sampai saat ini, diare masih menjadi salah satu masalah kesehatan di dunia, terutama di Negara berkembang. Masih tingginya angka kesakitan dan kematian akibat diare menjadi salah satu bukti bahwa diare masih membutuhkan perhatian khusus. Menurut data dari WHO tahun 2013, diare masih menjadi penyebab kematian terbesar kedua pada balita. Tiap tahunnya diare menyebabkan kematian pada 760.000 balita di seluruh dunia. Angka ini lebih besar dibandingkan dengan gabungan angka kematian balita karena AIDS, malaria dan campak. ${ }^{1,2}$ Berdasarkan data riset kesehatan dasar tahun 2013, insiden diare pada balita di Indonesia tahun 2013 adalah 6,7\% dengan period prevalence 7,0\%. Menurut karakteristik umur, kejadian diare tetinggi di Indonesia terjadi pada balita $(7,0 \%)$. Balita dengan insiden diare tertinggi berada pada kelompok umur 12 sampai 23 bulan $(9,7 \%){ }^{3}$

Di Bali, angka insiden diare pada balita adalah 5\% dengan period prevalence 5,5\%. ${ }^{3}$ Berdasarkan profil kesehatan Provinsi Bali tahun 2012, diperkirakan jumlah kasus diare sekitar 175.030 kasus. Jumlah ini meningkat dibandingkan dengan tahun 2011 sebesar 163.803 kasus. Perhitungan perkiraan kasus bahwa diantara 1000 orang penduduk, 411 orang mengalami diare dan hanya $10 \%$ yang datang ke pelayanan kesehatan. Jumlah perkiraan kasus diare di Kabupaten Karangasem adalah sebanyak 17.136 orang dari total 405.100 penduduk. Jumlah kasus yang tertangani adalah 7.620 kasus atau hanya $44,47 \%$ dari total perkiraan kasus. ${ }^{4}$ Jumlah kasus diare tahun 2013 berdasarkan data di Puskesmas Manggis I adalah sebanyak 592 orang dengan 44 orang $(7,43 \%)$ bayi dan 118 orang $(19,9 \%)$ balita. Setiap bulannya, rata-rata diperoleh 5 sampai 10 kasus diare pada balita pada tiap desa yang termasuk cakupan dari Puskesmas Manggis I. Di Desa Gegelang, kasus diare pada balita hampir selalu terjadi setiap bulan pada tahun $2013 .^{5}$

Derajat keparahan diare pada balita tergantung pada etiologi dan cara penanganan yang diberikan. Diare dapat dibedakan menjadi diare akut yang berlangsung kurang dari 14 hari dan diare persisten yang berlangsung lebih dari 14 hari. Penyebab tersering diare pada anak adalah infeksi baik yang terjadi di luar atau di dalam usus. Selain itu diare juga dapat disebabkan oleh obat-obatan, kelainan saluran cerna, defisiensi vitamin, ataupun tertelan logam berat. Diare akut pada anak biasanya disebabkan oleh rotavirus (40-60\%), 10\% disebabkan oleh infeksi bakteri. Diare yang tidak ditangani dengan baik dapat menyebabkan dehidrasi, gangguan elektrolit, dan keseimbangan asam basa akibat dari kehilangan air dan elektrolit. Apabila hal ini berlangsung lama, dapat terjadi malabsorpsi berat sehingga terjadi gangguan gizi dan/atau hipoglikemia. Komplikasi terburuk dari diare pada balita adaah kematian.,

Sebagai salah satu penyakit berbasis lingkungan, ketersediaan air bersih, sanitasi dan higenitas adalah salah satu pemegang peranan penting pada kejadian diare. Data WHO menunjukkan 88\% dari kasus diare disebabkan oleh konsumsi air yang tidak bersih dan sehat, sanitasi dan higenitas yang tidak memadai. WHO mengestimasikan 94\% kejadian diare dapat dicegah dengan modifikasi lingkungan termasuk peningkatan ketersediaan air bersih, dan peningkatan sanitasi dan higenitas. ${ }^{7}$ Sebagai salah satu upaya peningkatan sanitasi dan higenitas, Puskesmas Manggis I melakukan gerakan perilaku hidup bersih dan sehat (PHBS) di tingkat keluarga. PHBS tersebut terdiri dari persalinan ditolong tenaga kesehatan, pemberian ASI eksklusif, menimbang bayi dan balita setiap bulan, menggunakan air bersih, mencuci tangan dengan air bersih dan sabun, menggunakan jamban, memberantas jentik nyamuk di rumah, makan sayur dan buah setiap hari, melakukan aktivitas fisik setiap hari, dan tidak merokok. Untuk kegiatan PHBS di Puskesmas Manggis I, jumlah rumah tangga yang diklasifikasikan sehat yaitu sejumlah 897 KK (71,22\%). Jumlah ini belum menncapai target yang diharapkan yaitu $80 \%$. Persentase terendah rumah tangga yang diklasifikasikan sehat berdasarkan PHBS terletak di Desa Gegelang, yaitu hanya 46\%.5

Diantara 10 poin PHBS tersebut, penyebab diare pada balita dapat bersumber dari balita yang tidak mendapat ASI eksklusif, penggunaan air yang tidak bersih, kebiasaan tidak mencuci tangan dengan air bersih dan sabun, serta tidak memiliki jamban yang sehat. ${ }^{8}$ Tingkat pemberian ASI eksklusif di wilayah Puskesmas Manggis I tahun 2013 masih belum memenuhi target yaitu hanya 57,92\% dari target $80 \%$. Di Desa Gegelang, persentase pemberian ASI eksklusif pada tahun 2013 adalah sebesar 60\%. Pemberian ASI eksklusif sangat penting pada 6 bulan awal kehidupan anak. Salah satu fungsi ASI adalah memberikan kekebalan dari ibu ke anak sehingga anak tidak mudah tertular oleh penyakit. ${ }^{5}$

Air bersih adalah air yang digunakan utuk keperluan sehari-hari yang kualitasnya memenuhi syarat kesehatan dan dapat diminum apabila telah dimasak. Kualitas fisik air minum di Indonesia termasuk dalam katagori baik (tidak berwarna, tidak berasa, dan tidak berbau). ${ }^{9}$ Sumber air minum terlindung telah digunakan oleh $80,43 \%$ keluarga di Provinsi Bali, namun ini masih di bawah target yang diharapkan yaitu 100\%. Di Kabupaten Karangasem, akses air bersih mencapai 90,33\% pada tahun 2012, tetapi persentase keluarga yang 
diperiksa hanya $40,36 \%$ dari total keluarga yang tercatat. ${ }^{3}$ Di wilayah Puskesmas Manggis I, akses air bersih rata-rata mencapai $96 \%$ dari $90 \%$ total keluarga yang diperiksa. Di Desa Gegelang, akses air bersih mencapai 95\% dari 90\% jumlah keluarga yang diteliti pada tahun 2013. Ketersediaan akses air bersih di Desa Gegelang merupakan nomor dua terbawah dari total 6 Desa yang termasuk wilayah cakupan Puskesmas Manggis I. ${ }^{5}$

Jamban yang sehat adalah jamban yang memenuhi kriteria jamban sehat, antara lain tidak mencemari sumber air minum, tidak berbau dan tinja tidak dapat dijamah oleh serangga dan tikus, tidak mencemari tanah disekitarnya, mudah dibersihkan, dilengkapi dengan dinding dan atap pelindung, lantai kedap air dan luas ruangan memadai, serta tersedia air, sabun, dan alat pembersih. ${ }^{10}$ Data profil kesehatan Provinsi Bali tahu 2012 menyebutkan dari 64,34\% keluarga yang diperiksa di Bali tahun 2012, hanya $58,96 \%$ diantaranya yang memiliki jamban dan 90,12\% dari persentase tersebut memiliki jamban yang sehat. Di Karangasem, jumlah keluarga yang diperiksa adalah $31,35 \%$ dari total keluarga yang tercatat dan total keluarga yang memiliki jamban adalah $69,23 \%$ dan hanya $77,62 \%$ diantaranya yang memenuhi kriteria jamban sehat. ${ }^{4}$ Realisasi cakupan penggunaan jamban di wilayah Puskesmas Manggis I tahun 2013 hanya 68\%. Angka ini masih di bawah target 2013 yaitu $83 \%$. Dari 90\% keluarga yang diperiksa di Desa Gegelang, hanya 50\% keluarga yang memiliki jamban dan hanya 55\% diantaranya yang tergolong sehat. ${ }^{5}$

\section{METODE}

Penelitian ini mempergunakan rancangan penelitian deskriptif dengan pendekatan cross sectional. Penelitian ini dilaksanakan di Desa Gegelang, Kecamatan Manggis, Kabupaten Karangasem pada bulan Mei2014. Populasi penelitian ini adalah semua balita yang bertempat tinggal di Desa Gegelang yaitu sebanyak 284 orang. Sampel dalam penelitian ini balita berusia 1-5 tahun yang merupakan bagian dari populasi. Sampel diperoleh secara accidental sampling (non probability sampling) dari ibu yang memiliki balita berusia 1-5 tahun yang berada di wilayah Dusun Gegelang, Dusun Kalanganyar, dan Dusun Pakel, Desa Gegelang, Kecamatan Manggis, Kabupaten Karangasem dengan pertimbangan ketiga dusun tersebut merupakan dusun yang mudah diakses oleh peneliti. Besar sampel minimal yang diperlukan dalam penelitian ini adalah sebesar 71,74 orang. Peneliti menetapkan besar sampel dalam penelitian ini adalah 75 orang. Penambahan jumlah sampel dilakukan untuk menghindari berkurangnya sampel jika ada yang drop out karena berbagai alasan. Instrumen penelitian yang digunakan adalah pertanyaan dalam kuesioner yang dibuat oleh peneliti yang mengacu pada beberapa penelitan yang dilakukan sebelumnya dengan beberapa modifikasi. Analisis data dilakukan secara deskriptif dengan melihat distribusi jawaban responden terhadap setiap pertanyaan.

\section{HASIL}

\section{Karakteristik Responden}

Berikut ini adalah karakteristik responden yang terdiri atas alamat, usia, pendidikan, pekerjaan, dan penghasilan rata-rata per bulan.

Berdasarkan Tabel 1 karakteristik responden secara keseluruhan banyak diperoleh di dusun Pakel dan Kalanganyar. Usia tiap responden bervariasi dan terbanyak berada di rentang 26 sampai 35 tahun. Tingkat pendidikan yang tergambar seimbang antara pendidikan rendah dan pendidikan menengah. Mayoritas ibu tidak bekerja. Penghasilan rata-rata keluarga per bulan berkisar Rp 500.000,00 sampai Rp 3.000.000,00.

\section{Tabel 1 Karakteristik Responden}

\begin{tabular}{|c|c|c|}
\hline Karakteristik & $\begin{array}{c}\text { Jumlah } \\
\text { (n) }\end{array}$ & $\begin{array}{c}\text { Persentase } \\
(\%)\end{array}$ \\
\hline \multicolumn{3}{|l|}{ Alamat } \\
\hline Dusun/Banjar Gegelang & 11 & 14,7 \\
\hline Dusun/Banjar Kalanganyar & 26 & 34,7 \\
\hline Dusun/Banjar Pakel & 38 & 50,7 \\
\hline \multicolumn{3}{|l|}{ Usia } \\
\hline$<26$ tahun & 17 & 22,7 \\
\hline 26-35 tahun & 49 & 65,3 \\
\hline$>35$ tahun & 9 & 12,0 \\
\hline \multicolumn{3}{|l|}{ Pendidikan } \\
\hline Pendidikan rendah & 37 & 49,3 \\
\hline Pendidikan menengah & 37 & 49,3 \\
\hline Pendidikan tinggi & 1 & 1,4 \\
\hline \multicolumn{3}{|l|}{ Pekerjaan } \\
\hline Karyawan & 18 & 24,0 \\
\hline Pedagang & 5 & 6,7 \\
\hline Buruh & 11 & 14,7 \\
\hline Petani & 4 & 5,3 \\
\hline Tidak bekerja & 37 & 49,3 \\
\hline \multicolumn{3}{|l|}{ Penghasilan rata-rata per bulan } \\
\hline Rp 100.000- Rp 500.000 & 17 & 22,7 \\
\hline Rp 500.000- Rp 1.000.000 & 29 & 38,7 \\
\hline Rp 1.000.000- Rp 3.000.000 & 29 & 38,7 \\
\hline
\end{tabular}


Tabel 2 Karakteristik Sampel

\begin{tabular}{lcc}
\hline Karakteristik & Jumlah $(\mathbf{n})$ & Persentase (\%) \\
\hline Usia & & \\
12-36 bulan & 45 & 60,0 \\
37-60 bulan & 30 & 40,0 \\
Jenis Kelamin & & \\
Laki-laki & 39 & 52,0 \\
Perempuan & 36 & 48,0 \\
\hline
\end{tabular}

Tabel 3 Jumlah Riwayat Kejadian Diare pada Balita dan Pelaksanaan PHBS dalam Tatanan Rumah Tangga

\begin{tabular}{lcc}
\hline & Jumlah (n) & Persentase (\%) \\
\hline Riwayat diare dalam setahun & & \\
$\quad$ Tidak pernah & 13 & 17,3 \\
1 sampai 2 kali & 50 & 66,7 \\
Lebih dari 2 kali & 12 & 16,0 \\
Riwayat ASI eksklusif & & \\
$\quad$ Dengan ASI eksklusif & 22 & 29,3 \\
$\quad$ Tanpa ASI eksklusif & 53 & 70,7 \\
Ketersediaan akses air bersih & & \\
$\quad$ Tersedia & 75 & 100 \\
Kelayakan air minum & & \\
$\quad$ Layak & 32 & 42,7 \\
$\quad$ Tidak layak & 43 & 57,3 \\
Kebiasaan cuci tangan & & \\
Baik & 30 & 40,0 \\
Tidak baik & 45 & 60,0 \\
Kepemilikan jamban & & 38,7 \\
$\quad$ Memiliki dan sesuai standar & 29 & 25,3 \\
$\quad$ Memiliki tetapi tidak sesuai & 19 & 36,0 \\
$\quad$ standar & 27 & \\
Tidak memiliki & &
\end{tabular}

Karakteristik Sampel

Berikut ini adalah karakteristik sampel yang terdiri atas usia dan jenis kelamin.

Berdasarkan Tabel 2 karakteristik sampel secara keseluruhan cukup merata baik berdasarkan rentang usia dan jenis kelamin.

\section{Gambaran Jumlah Riwayat Kejadian Diare pada Balita dan PHBS dalam Tatanan Rumah Tangga}

Berikut merupakan tabel hasil penelitian mengenai jumlah riwayat kejadian diare pada balita dan pelaksanaan PHBS dalam tatanan rumah tangga yang meliputi riwayat pemberian ASI eksklusif, ketersediaan akses air bersih, kelayakan air minum, kebiasaan cuci tangan dengan air bersih dan sabun, serta ketersediaan jamban.
Tabel 3 menunjukkan bahwa hanya 13 dari 75 $(17,3 \%)$ responden mengatakan bahwa anaknya pernah mengalami diare dalam 1 tahun terakhir. Sebanyak 53 responden (70,7\%) menyatakan tidak memberikan ASI eksklusif pada anaknya. Seluruh responden memiliki akses air bersih, tetapi hanya 32 dari $75(42,7 \%)$ responden yang memenuhi kriteria air yang layak untuk diminum. Kebiasaan cuci tangan yang baik dan benar hanya tergambar pada 30 dari 75 (40\%) responden. Kepemilikan jamban bervariasi mulai dari memiliki dan sesuai standar $(38,7 \%)$, memiliki tetapi tidak sesuai standar $(25,3 \%)$, dan tidak memiliki jamban (36.0\%).

\section{Gambaran Jumlah Riwayat Kejadian Diare terhadap PHBS dalam Tatanan Rumah Tangga}

Berikut merupakan sajian yang menampilkan gambaran jumlah riwayat kejadian diare dengan riwayat pemberian ASI eksklusif, kelayakan air minum, kebiasaan cuci tangan dengan air dan sabun, serta kepemilikan jamban dalam tabel tabulasi silang untuk analisis kecenderungan yang terjadi antara riwayat jumlah kejadian diare dan beberapa poin pelaksanaan PHBS dalam tatanan rumah tangga.

Hasil tabulasi silang pada Tabel 4 menunjukkan kecenderungan frekuensi kejadian diare lebih dari 2 kali dalam setahun lebih banyak $((22,6 \%)$ pada balita tanpa riwayat ASI eksklusif dibandingkan dengan balita dengan riwayat ASI eksklusif $(0,0 \%)$. Tabel 4 juga menunjukkan kecederungan proporsi balita yang tidak mengalami diare lebih tinggi pada responden yang memiliki air minum yang sesuai dengan standar kelayakan $(40,6 \%)$ dibandingkan dengan responden yang memiliki air minum yang tidak sesuai dengan standar kelayakan $(0,0 \%)$. Balita dari responden yang memiliki kebiasaan cuci tangan yang baik cenderung memiliki proporsi tidak mengalami diare yang lebih tinggi $(40,0 \%)$ jika dibandingkan dengan balita dari responden yang memiliki kebiasaan cuci tangan yang tidak baik. Proporsi kejadian diare balita lebih dari 2 kali dalam setahun cenderung lebih tinggi pada responden yang tidak memiliki jamban dibandingkan dengan responden yang memiliki jamban yang sesuai standar $(0,0 \%)$ ataupun yang memiliki jamban tetapi tidak sesuai standar (5,3\%). Sementara itu, pada responen yang memiliki jamban dan sesuai kriteria jamban sehat, proporsi balita yang tidak mengalami diare lebih tinggi $(37,9 \%)$ dibandingkan dengan responden yang memiliki jamban tetapi tidak memenuhi kriteria jamban sehat $(10,5 \%)$ dan responden yang tidak memiliki jamban $(0,0 \%)$. 
Tabel 4 Tabulasi Silang antara Jumlah Riwayat Kejadian Diare dengan pelaksanaan PHBS dalam Tatanan Rumah Tangga

\begin{tabular}{|c|c|c|c|c|}
\hline & \multicolumn{3}{|c|}{ Jumlah Riwayat Kejadian Diare dalam 1 tahun } & \multirow[b]{2}{*}{ Total } \\
\hline & Tidak Pernah & 1-2 kali & 2 kali & \\
\hline \multicolumn{5}{|l|}{ Riwayat ASI eksklusif } \\
\hline $\begin{array}{l}\text { Dengan ASI } \\
\text { eksklusif }\end{array}$ & $\begin{array}{c}6 \\
7,3 \%\end{array}$ & $\begin{array}{c}16 \\
72,7 \%\end{array}$ & $\begin{array}{c}0 \\
0,0 \%\end{array}$ & $\begin{array}{c}22 \\
100 \%\end{array}$ \\
\hline $\begin{array}{l}\text { Tanpa ASI } \\
\text { eksklusif }\end{array}$ & $\begin{array}{c}7 \\
13,2 \%\end{array}$ & $\begin{array}{c}34 \\
64,2 \%\end{array}$ & $\begin{array}{c}12 \\
22,6 \%\end{array}$ & $\begin{array}{c}53 \\
100 \%\end{array}$ \\
\hline \multicolumn{5}{|l|}{ Kelayakan air minum } \\
\hline Layak & $\begin{array}{c}13 \\
40,6 \%\end{array}$ & $\begin{array}{c}19 \\
59,4 \%\end{array}$ & $\begin{array}{c}0 \\
0,0 \%\end{array}$ & $\begin{array}{c}32 \\
100 \%\end{array}$ \\
\hline Tidak layak & $\begin{array}{c}0 \\
0,0 \%\end{array}$ & $\begin{array}{c}3 \\
72,1 \%\end{array}$ & $\begin{array}{c}12 \\
26,7 \%\end{array}$ & $\begin{array}{c}43 \\
100 \%\end{array}$ \\
\hline \multicolumn{5}{|l|}{ Kebiasaan cuci tangan } \\
\hline Baik & $\begin{array}{c}12 \\
40,0 \%\end{array}$ & $\begin{array}{c}18 \\
60,0 \%\end{array}$ & $\begin{array}{c}0 \\
0,0 \%\end{array}$ & $\begin{array}{c}30 \\
100 \%\end{array}$ \\
\hline Tidak baik & $\begin{array}{c}1 \\
2,2 \%\end{array}$ & $\begin{array}{c}32 \\
71,1 \%\end{array}$ & $\begin{array}{c}12 \\
26,7 \%\end{array}$ & $\begin{array}{c}45 \\
100 \%\end{array}$ \\
\hline \multicolumn{5}{|l|}{ Kepemilikan jamban } \\
\hline $\begin{array}{l}\text { Memiliki dan } \\
\text { sesuai standar }\end{array}$ & $\begin{array}{c}11 \\
37,9 \%\end{array}$ & $\begin{array}{c}18 \\
62,1 \%\end{array}$ & $\begin{array}{c}0 \\
0,0 \%\end{array}$ & $\begin{array}{c}29 \\
100 \%\end{array}$ \\
\hline $\begin{array}{l}\text { Memiliki tetapi } \\
\text { tidak sesuai } \\
\text { standar }\end{array}$ & $\begin{array}{c}2 \\
10,5 \%\end{array}$ & $\begin{array}{c}16 \\
59,3 \%\end{array}$ & $\begin{array}{c}1 \\
5,3 \%\end{array}$ & $\begin{array}{c}19 \\
100 \%\end{array}$ \\
\hline Tidak memiliki & $\begin{array}{c}0 \\
0,0 \%\end{array}$ & $\begin{array}{c}16 \\
59,3 \%\end{array}$ & $\begin{array}{c}11 \\
40,7 \%\end{array}$ & $\begin{array}{c}27 \\
100 \%\end{array}$ \\
\hline
\end{tabular}

\section{DISKUSI}

\section{Karakteristik Responden dan Sampel}

Hasil penelitian pada tabel 1 menunjukkan gambaran usia responden terbanyak adalah kelompok dewasa awal (26 sampai 35 tahun) yaitu sebesar $65,3 \%$. Ini menandakan usia ibu balita masih tergolong kelompok usia produktif yang masih aktif sehingga dapat selalu berusaha mencari informasi yang berkaitan dengan diare pada balita. Kelompok usia dewasa awal akan cenderung lebih aktif dan reaktif sehingga akan lebh cepat dalam mengakses informasi. Usia memiliki pengaruh yang besar dalam hubungannya dengan penyakit, kondisi cidera, penyakit kronis, dan penyakit lain. ${ }^{11}$ Bertambahnya usia seseorang akan meningkatkan kedewasaan teknisnya demikian pula psikologis serta menunjukkan kematangan jiwa. Pertambahan usia juga dapat meningkatkan kemampuan seseorang dalam mengambil keputusan, berpiki rasional, mengendalikan emosi, dan bertoleransi terhadap pandangan orang lain yang berpengaruh pada peningkatan motivasi. ${ }^{11}$ Pada penelitian ini harus diperhatikan usia ibu karena dengan bertambahnya usia ibu akan meningkatkan pengalaman ibu dalam merawat balita yang mengalami diare, karena pengalaman akan mengubah perilaku yang tidak baik menjadi baik.

Dilihat dari tingkat pendidikan ibu, persentase hasil yang seimbang diperoleh pada tingkat pendidikan yang rendah dan menengah (49,3\%). Pendidikan dapat memperbaiki perilaku kesehatan serta membantu mencegah penyakit. Hal ini akan tercermin dari pengetahuan, sikap, dan perilaku ibu terhadap diare. Tingkat pendidikan ibu akan mempengaruhi kesadaran akan pentingnya arti kesehatan bagi diri dan lingkungan yang dapat mendorong kebutuhan akan pelayanan kesehatan. Seseorang dengan tingkat pendidikan rendah cenderung akan memiliki pengetahuan yang lebih rendah dibandingkan dengan seseorang dengan pendidikan menengah dan tinggi. Pendidikan ibu yang baik akan mempengaruhi proses penerimaan informasi kesehatan terkait diare. Kejadian diare pada balita dapat menurun dengan tingkat pendidikan ibu yang lebih tinggi. ${ }^{11}$

Karakteristik ekonomi dalam penelitian tergambar dari penghasilan rata-rata keluarga per bulan yang menunjukkan hanya 38,7\% dari responden yang memiliki penghasilan diatas Rp 1.000.000,00. Selain itu, hasil penelitian menunjukkan sebagian besar ibu $(49,3 \%)$ tidak bekerja dan bekerja sebagai buruh lepas dengan penghasilan yang tidak menentu sebanyak $14,7 \%$. Hal ini menunjukkan status ekonomi responden secara menyeluruh masih rendah. Sumber pendapatan keluarga menentukan kemampuan seseorang dalam menjangkau akses pelayanan kesehatan. Selain itu, ketersediaan sarana untuk penerapan PHBS di keluarga membutuhkan ketersediaan sumber pendapatan keluarga yang baik. Permasalahan penyakit diawali masalah kesehatan berakar dari kemiskinan. Permasalahan kesehatan dapat dikendalikan apabila angka kemiskinan menurun dan status ekonomi meningkat. ${ }^{11}$

Hasil penelitian pada tabel 2 menunjukkan sebagian besar sampel yang diteliti berusia 12 sampai 36 bulan dengan jumlah 45 orang (60\%) dan usia 37 sampai 60 bulan sebanyak 30 orang (40\%). Kejadian diare pada balita usia 12 sampai 36 ulan cenderung lebih tinggi $(91,1 \%)$ dibandingkan dengan balita usia 37 sampai 60 bulan (70\%). Hal ini sesuai dengan hasil RISKESDAS tahun 2013 dimana insiden diare pada balita ditemukan paling tinggi pada rentang usia 12 sampai 23 bulan $(7,6 \%)$ diikuti dengan rentang usia 24 sampai 35 bulan $(5,8 \%){ }^{3}$ Sebanyak 39 sampel (52\%) yang diteliti berjenis kelamin lakilaki dan sisanya (48\%) adalah perempuan. Riwayat kejadian diare cenderung lebih tinggi pada balita berjenis kelamin laki-laki (87,2\%) dibandingan dengan balita perempuan (77,8\%). Hasil ini sesuai dengan RISKESDAS tahun 2013 dimana insiden diare pada balita lebih tinggi pada laki-laki $(5,5 \%)$ dibandingkan dengan perempuan (4,9\%). ${ }^{3}$ 


\section{Gambaran Jumlah Riwayat Kejadian Diare pada Balita dan PHBS dalam Tatanan Rumah Tangga Gambaran Jumlah Riwayat Kejadian Diare}

Dari penelitian ini, diperoleh hasil sebagian besar sampel pernah mengalami diare dalam kurun waktu 1 tahun. Sebanyak 66,7 sampel mengalami diare sebanyak 1 sampai 2 kali dalam setahun dan $16 \%$ mengalami diare sebanyak lebih dari 2 kali dalam setahun. Hasil ini cukup tinggi melihat data awal yang terdapat di Puskesmas Manggis I dimana tercatat hanya 118 orang balita yang berobat ke Puskesmas karena diare. Kondisi ini dimungkinkan karena tidak semua ibu yang memiliki anak dengan riwayat diare membawa anaknya ke Puskesmas untuk diobati. Sebagian besar ibu mengaku mengobati anaknya sendiri dengan memberikan larutan gula garam atau membelikan oralit di toko obat. Selain itu, beberapa ibu juga membawa anaknya ke praktek dokter atau bidan swasta sehingga tidak masuk dalam pencatatan di Puskesmas. Berdasarkan survey morbiditas yang dilakukan oleh Subdit diare, Departemen Kesehatan dari tahun 2000 sampai dengan 2010 terlihat kecenderungan insiden yang naik dimana pada tahun 2010 angka insiden diare adalah 411 per 1000 penduduk. ${ }^{12}$

Penelitian yang dilakukan oleh Nuraeni tahun 2012 di wilayah Puskesmas Tawangmas Kota Semarang menunjukkan angka insiden diare sebesar 36,7\%. Angka ini juga termasuk tinggi jika dibandingkan dengan hasil Riskesdas 2007 prevalensi diare di Jawa Tengah sebesar 9,2\%. ${ }^{11}$ Penyebab tingginya angka insiden yang diperoleh dikarenakan beberapa dari balita yang mengalami diare dirawat di rumah dan tidak dibawa ke pusat pelayanan kesehatan. ${ }^{11}$ Penyakit diare di Indonesia merupakan salah satu masalah kesehatan masyarakat karena tingginya angka kesakitan dan angka kematian akibat diare. Berdasarkan Survei Kesehatan Rumah Tangga, studi mortalitas dan Riskesdas dari tahun ke tahun diketahui bahwa diare masih menjadi penyebab utama kematian balita di Indonesia. ${ }^{11}$

Diare menempati posisi teratas penyebab kesakitan dan kematian karena penyakit infeksi, diamana angka kematian mencapai 1,8 juta di dunia dengan angka kesakitan mencapai 4 milyar kasus per tahun. Balita merupakan kelompok umur yang paling sering mengalami kematian akibat diare, terutama di Negara berkembang. WHO mengestimasikan 94\% kasus diare dapat dicegah dengan modifikasi lingkungan, salah satunya dengan meningkatkan ketersediaan akses air bersih dan kelayakan air minum, serta meningkatkan sanitasi dan kebersihan lingkungan. ${ }^{7}$ Penelitian yang dilakukan oleh Bateman dkk (2009) menunjukkan terdapat penurunan episode kejadian diare yang signifikan sebanyak $25 \%$ terhadap peningkatan ketersediaan akses air bersih, 32\% terhadap peningkatan sanitasi, $45 \%$ terhadap peningkatan kebiasaan cuci tangan yang baik dan benar, dan $39 \%$ terhadap peningkatan teknik pengelolaan air yang benar serta pembuangan yang aman.

\section{Gambaran Riwayat Pemberian ASI eksklusif}

Dari penelitian diperoleh hasil hanya 22 dari 75 sampel (29,3\%) yang memperoleh ASI eksklusif. Hasil ini rendah bila dibandingkan dengan target nasional pemberian ASI eksklusif sebesar $80 \%$. Data Riskesdas 2013 mennjukkan bahwa cakupan ASI eksklusif rata-rata nasional baru sekitar 15,3\%. ${ }^{3}$ Alasan yang diutarakan responden yang tidak memberikan ASI eksklusif antara lain ASI tidak keluar atau keluar sedikit sehingga tidak mampu memenuhi kebutuhan bayi, ibu yang bekerja, dan beberapa responden mengaku masih tidak tahu jika bayi yang berumur kurang dari 6 bulan tidak boleh dimerikan makanan atau minuman dalam bentuk apapun selain ASI, termasuk air putih.

Tingkat pemberian ASI eksklusif yang rendah akan meningkatkan angka kejadian infeksi pada bayi. ${ }^{13}$ Pemberian ASI eksklusif dapat membantu meningkatkan daya tahan tubuh bayi. ASI mengandung sIgA, limfosit $\mathrm{T}$, limfosit $\mathrm{B}$, dan laktoferin yang dapat merangsang peningkatan status imun pada bayi. IgA sekretoris yang didapatkan bayi dari ASI sangat membantu kemampuan tubuhnya dalam menghalangi mikroorganisme dan menjauhkannya dari jaringan tubuh. Ibu membentuk antibodi yang bersifat spesifik pada agen penyakit sehingga dapat melindungi bayi pada minggu-minggu awal kehidupan. Seperti molekul pertahanan lainnya, sel-sel imun pada ASI juga mengandung sel-sel darah putih atau leukosit yang dapat melawan agen infeksius. Kandungan sel darah putih ini paling banyak terdapat pada kolustrum. Tipe yang paling banyak ditemukan adalah neutrofil yang dapat bersikulasi dalam aliran darah. Tipe lainnya yang juga ditemukan dalam ASI adalah makrofag. Komponen lainnya yang terdapat dalam ASI merangsang produksi IgA sekretorik, laktoferik dan lisozim oleh bayi itu sendiri. ${ }^{14}$

Menurut penelitian Matondang, dkk (2009) ASI merupakan komponen penting pada sistem imun mukosa gastrointestinal maupun mukosa lain. Penelitian lain yang dilakukan oleh Tumbelaka dan Karyanti (2009) menyebutkan bahwa angka kejadian infeksi pada bayi lebih sedikit bila dibandingkan dengan bayi yang tidak mendapatkan ASI. Hasil tabulasi silang antara riwayat pemberian ASI eksklusif dan jumlah riwayat kejadian diare dalam setahun pada sampel menunjukkan kecenderungan frekuensi kejadian diare lebih dari 2 kali dalam setahun lebih banyak (22,6\%) pada balita 
tanpa riwayat ASI eksklusif dibandingkan dengan balita dengan riwayat ASI eksklusif $(0,0 \%)$. Hasil ini sesuai dengan penelitian yang dilakukan oleh Nuraeni (2012) menunjukkan terdapat perbedaan yang bermakna antara pemberian ASI eksklusif dengan kejadian diare pada balita dengan nilai $\mathrm{p}=0,003$. Bslita yang tidak diberi ASI secara eksklusif dapat berisiko 4,483 kali terkena diare dibandingkan dengan balita yang mendapatkan ASI secara eksklusif. Hasil yang sama juga ditunjukkan oleh penelitian yang dilakukan Rahmadahani, dkk (2013) yang menyatakan bahwa terdapat hubungan yang signifikan antara pemberian ASI eksklusif dan kejadian diare. Semakin lama bayi diberi ASI secara eksklusif semakin kecil kemungkinan bayi untuk terkena kejadian diare. Hal ini dikarenakan zat antibodi yang diperoleh bayi dari ASI mampu melindungi bayi dari berbagai macam penyakit infeksi. ${ }^{15}$ Pemberian ASI selama diare mengurangi akibat negatif terhadap pertumbuhan dan keadaan gizi bayi serta mengurangi keparahan diare. ${ }^{11}$

\section{Gambaran Ketersediaan Akses Air Bersih}

Hasil penelitian menunjukkan seluruh responden memiliki akses air bersih (100\%). Hal ini sesuai dengan data di Puskesmas Manggis I dimana 95\% dari $90 \%$ total jumlah keluarga yang diteliti tahun 2013 telah memiliki akses air bersih (DINKES Pemkab Karangasem, 2013). Akan tetapi, dari 75 responden yang memiliki akses air bersih, hanya 32 responden $(42,7 \%)$ yang memenuhi kriteria air minum yang layak. Sebanyak 57,3\% responden langsung mengonsumsi air bersih yang bersumber dari air ledeng tanpa dimasak hingga mendidih terlebih dahulu. Alasan yang mereka utarakan adalah karena air yang mereka peroleh sudah jernih, tidak berwarna, tidak berasa, maupun berbau.

Kriteria kelayakan air dapat diukur secara kualitas dan kuantitas. Sistem penyediaan air bersih harus memenuhi persyaratan fisik, kimia, dan biologis. Syarat fisik yakni tidak keruh, tidak berwarna, rasanya tawar, tidak berbau, suhunya normal $\left(20-26^{\circ} \mathrm{C}\right)$ dan tidak mengandung zat padat. Syarat kimia meliputi tidak mengandung zat kimia beracun, $\mathrm{pH}$ netral, tidak mengandung garam-garam atau ion-ion logam, kesadahan rendah, dan tidak mengandung bahan kimia anorganik. Syarat biologis yakni air tidak boleh mengandung Coliform. Air bersih yang telah memenuhi syarat-syarat tersebut selanjutnya harus diolah terlebih dahulu sebelum dikonsumsi. Pengolahan dapat berupa penyulingan dimana biasanya air tersedia dalam bentuk air kemasan atau air dimasak hingga mendidih terlebih dahulu sebelum dikonsumsi untuk membunuh patogen yang terdapat dalam air tersebut. ${ }^{16}$

Hasil tabulasi silang antara jumlah riwayat kejadian diare dengan kelayakan air minum responden menunjukkan kecenderungan proporsi balita yang tidak mengalami diare lebih tinggi pada responden yang memiliki air minum yang sesuai dengan standar kelayakan $(40,6 \%)$ dibandingkan dengan responden yang memiliki air minum yang tidak sesuai dengan standar kelayakan $(0,0 \%)$. Hasil ini sesuai dengan penelitian yang dilakukan oleh Nuraeni (2012) yang menunjukkan adanya hubungan yang bermakna antara penggunaan ai bersih dengan kejadian diare pada balita dengan nilai $\mathrm{p}=0,000$. Penelitian ini juga menyebutkan penggunaan air bersih yang tidak baik dapat berisiko 10,311 kali terkena diare. Diare juga dapat terjadi karena pencemaran air oleh bakteri saat pengambilan, pengolahan, maupun penyimpanan air, serta perilaku masyarakat saat memasak dan memanfaatkan sarana tersebut. Hal yang sama juga diperoleh dari hasil penelitian Apriyanti, dkk (2009) yang menyatakan diare bisa disebabkan oleh masih sedikitnya masyarakat yang mengelola air minum rumah tangga dengan baik. Berdasarkan ringkasan kajian yang dikeluarkan oleh UNICEF Indonesia (2012) sanitasi dan perilaku kebersihan yang buruk serta air minum yang tidak aman berkontribusi terhadap 88\% kematian anak akibat diare.

\section{Gambaran Kebiasaan Cuci Tangan dengan Air dan Sabun}

Berdasarkan hasil penelitian, terlihat bahwa hanya $40 \%$ dari total responden yang masuk ke dalam kategori baik untuk perilaku mencuci tangan. Sebagian besar responden masih mencuci tangan hanya dengan air tanpa menggunakan sabun saat sebelum makan, setelah $\mathrm{BAB} / \mathrm{BAK}$, sebelum mengolah makanan, setelah menyajikan makanan, setelah membasuh anak BAB, dan sebelum menyuapi anak dengan tangan. Mereka mengaku mencuci tangan menggunakan sabun hanya ketika tangan mereka terlihat kotor saja.

Mencuci tangan harus dilakukan dengan cara yang benar dan waktu yang tepat. Mencuci tangan hendaknya menggunakan sabun dan air mengalir baik langsung dari keran air ataupun langsung mengalir dari gayung sehingga kotoran yang menempel pada tangan dapat langsung dibersihkan. ${ }^{16}$ Cuci tangan pakai air saja tidak cukup karena cuci tangan pakai sabun selain membantu singkatnya waktu cuci tangan, dengan menggosok jemari dengan sabun dapat juga menghilangkan kuman yang tidak tampak, kotoran di permukaan kulit, tangan berbau wangi, serta perasaan segar. ${ }^{16,17}$

Hasil tabulasi silang menunjukan kecenderungan balita dari responden yang memiliki kebiasaan cuci tangan yang baik cenderung memiliki proporsi tidak mengalami diare yang lebih tinggi $(40,0 \%)$ jika dibandingkan dengan balita dari responden yang memiliki kebiasaan cuci tangan yang tidak baik. 
Hal ini sesuai dengan hasil penelitian Wijayanti (2009) yang menyatakan bahwa terdapat hubungan yang signifikan antara cuci tangan pakai sabun dengan angka kejadian diare di daerah sekitar TPA sampah Bantar Gebang. Hasil serupa juga diperoleh dari penelitian yang dilakukan oleh Wardayu dan Guritmo (2010) yang menyatakan terdapat hubungan yang signifikan antara kebiasaan cuci tangan setelah $B A B$ dengan kejadian diare $(p=0,024)$, kebiasaan mencuci tangan sebelum menyuapi anak dengan kejadian diare $(\mathrm{p}=0,02)$.

Mencuci tangan dengan sabun dan air mengalir merupakan aktivitas yang selama ini dianggap sederhana oleh kebanyakan orang, bahkan ada anggapan masyarakat bahwa cuci tangan tanpa menggunakan sabun sama saja dengan menggunakan sabun. ${ }^{17}$ Tetapi sebaliknya bahwa mencuci tangan pakai sabun sebenarnya banyak manfaatnya. Tangan memegang peranan penting dalam penularan diare karena lewat tangn yang tidak bersih makanan atau minuman yang tercemar penyakit masuk ke tubuh manusia. Tangan merupakan pembawa utama mikroorganisme yang berasal dari tinja. Tujuan cuci tangan dengan sabun adalah menghilangkan kotoran dan debu yang melekat dipermukaan kulit serta mengurangi jumlah mikroorganisme sementara. ${ }^{11}$ Menurut kajian Badan Kesehatan Dunia, cuci tangan pakai sabun dengan cara yang benar dan pada waktu-waktu yang tepat terbukti mencegah angka kejadian diare hingga $45 \%{ }^{1}$

\section{Gambaran Kepemilikan Jamban}

Hasil penelitian menunjukkan kepemilikan jamban bervariasi dari responden mulai dari memiliki dan sesuai standar kesehatan $(38,7 \%)$, memiliki tetapi tidak sesuai standar kesehatan $(25,3 \%)$, dan tidak memiliki jamban (36,0\%). Responden yang tidak memiliki jamban mengaku belum bisa membuatnya di rumah karena terhalang masalah ekonomi dimana harga bahan-bahan baku untuk membuat jamban cukup mahal. Alasan yang mirip juga dikemukakan oleh responden yang memiliki jamban tetapi tidak sesuai standar. Mereka mengatakan hanya mampu membuat jamban seadanya. Mereka tidak memiliki penghasilan lebih untuk merenovasi jamban agar sesuai dengan standar kesehatan yang ditetapkan. Sebagian besar responden yang tidak memiliki jamban membuang tinja mereka dan tinja balita ke sungai dan/atau kebun di dekat rumah mereka. WC umum belum banyak tersedia di desa Gegelang. Terdapat 1 WC umum di Dusun Gegelang, tetapi belum tersedia di Dusun Kalanganyar dan Pakel.

Penggunaan jamban yang baik dan sehat adalah tidak ada tinja yang tertinggal (menempel) disekitar jamban dan jamban rajin dibersihkan dan disikat. Karakteristik jamban yang baik adalah tidak mengotori permukaan tanah di sekitarnya, tidak mengotori air permukaan di sekitarnya, tidak mengotori air tanah dalam sekitarnya, dapat digunakan oleh semua anggota keluarga. Jamban berjarak sekurang-kurangnya 10 meter dari sumber air dan pemukiman, tendon penampungan tinja sekurang-kurangnya 1 meter, serta tidak memungkinkan lalat atau serangga hinggap di tampungan tinja (dengan sistem leher angsa) sehingga tidak dapat dipakai sebagai tempat vektor bertelur dan berkembang biak. ${ }^{10,11}$

Berdasarkan hasil tabulasi silang antara jumlah riwayat kejadian diare pada balita dengan kepemilikan jamban terdapat kecenderungan pada responden yang memiliki jamban dan sesuai kriteria jamban sehat, proporsi balita yang tidak mengalami diare lebih tinggi (37,9\%) dibandingkan dengan responden yang memiliki jamban tetapi tidak memenuhi kriteria jamban sehat $(10,5 \%)$ dan responden yang tidak memiliki jamban $(0,0 \%)$. Hasil penelitian ini sejalan dengan hasil penelitian Apriyanti, dkk (2009) yang menyatakan terdapat hubungan yang signifikan antara penggunaan jamban ( $p$ value $=0,046$; $\alpha=0,05)$ dengan angka kejadian diare pada anak. Hasil yang sama juga diperoleh dari penelitian yang dilakukan Wulandari (2009) yang menyatakan ada hubungan signifikan antara jenis tempat pembuangan tinja dengan kejadian diare di Desa Blimbing yaitu dengan nilai $p=0,001$, $(p<0,05)$. Hal ini disebabkan karena masyarakat masih banyak yang belum memiliki jamban sehat. Jenis jamban yang tidak sehat yaitu jenis jamban tangki septik atau jamban cemplung dan rumah yang tidak memiliki jamban sehinggan bila buang air besar mereka pergi ke sungai. Jenis tempat pembuangan tinja yang tidak memenuhi syarat kesehatan akan berdampak pada banyaknya lalat. Tinja yang dibuang di tempat terbuka dapat digunakan oleh lalat untuk bertelur dan berkembang biak kemudian lalat tersebut hinggap di kotoran manusia dan hinggap pada makanan manusia. Lalat berperan dalam penularan penyakit melalui tinja. ${ }^{18}$

Pembuangan tinja merupakan bagian yang penting dari kesehatan. Pembuangan tinja yang tidak tepat dapat berpengaruh langsung terhadap insiden penyakit tertentu yang penularannya melalui tinja, salah satunya adalah diare. Belum memiliki jamban sendiri dapat menyebabkan timbulnya kejadian diare pada balita yang dikarenakan kotoran yang tidak terkubur akan mengundang lalat maupun tikus yang akan berdampak terhadap kesehatan lingkungan. ${ }^{19}$ 


\section{SIMPULAN}

Berdasarkan hasil penelitian yang dilakukan di Desa Gegelang tentang gambaran jumlah riwayat kejadian diare pada balita dan pelaksanaan PHBS dalam tatanan rumah tangga, maka dapat disimpulkan bahwak karakteristik responden secara keseluruhan banyak diperoleh di dusun Pakel dan Kalanganyar. Usia tiap responden bervariasi dan terbanyak berada di rentang 26 sampai 35 tahun. Tingkat pendidikan yang tergambar seimbang antara pendidikan rendah dan pendidikan menengah. Mayoritas ibu tidak bekerja. Penghasilan rata-rata keluarga per bulan berkisar Rp 500.000,00 sampai $\mathrm{Rp}$ 3.000.000,00. Karakteristik sampel secara keseluruhan cukup merata baik berdasarkan rentang usia dan jenis kelamin. Sebanyak 13 dari $75(17,3 \%)$ responden mengatakan bahwa anaknya pernah mengalami diare dalam 1 tahun terakhir. Sebanyak 53 responden $(70,7 \%)$ menyatakan tidak memberikan ASI eksklusif pada anaknya. Seluruh responden memiliki akses air bersih, tetapi hanya 32 dari $75(42,7 \%)$ responden yang memenuhi kriteria air yang layak untuk diminum. Kebiasaan cuci tangan yang baik dan benar hanya tergambar pada 30 dari 75 (40\%) responden. Kepemilikan jamban bervariasi mulai dari memiliki dan sesuai standar, memiliki tetapi tidak sesuai standar, dan tidak memiliki jamban. Hasil tabulasi silang antara jumlah riwayat kejadian diare pada balita dan pelaksanaan PHBS menunjukkan kecenderungan frekuensi kejadian diare lebih dari 2 kali dalam setahun lebih banyak $((22,6 \%)$ pada balita tanpa riwayat ASI eksklusif dibandingkan dengan balita dengan riwayat ASI eksklusif (0,0\%). Kecederungan proporsi balita yang tidak mengalami diare lebih tinggi pada responden yang memiliki air minum yang sesuai dengan standar kelayakan (40,6\%) dibandingkan dengan responden yang memiliki air minum yang tidak sesuai dengan standar kelayakan $(0,0 \%)$. Balita dari responden yang memiliki kebiasaan cuci tangan yang baik cenderung memiliki proporsi tidak mengalami diare yang lebih tinggi $(40,0 \%)$ jika dibandingkan dengan balita dari responden yang memiliki kebiasaan cuci tangan yang tidak baik. Proporsi kejadian diare balita lebih dari 2 kali dalam setahun cenderung lebih tinggi pada responden yang tidak memiliki jamban dibandingkan dengan responden yang memiliki jamban yang sesuai standar $(0,0 \%)$ ataupun yang memiliki jamban tetapi tidak sesuai standar (5,3\%). Sementara itu, pada responen yang memiliki jamban dan sesuai kriteria jamban sehat, proporsi balita yang tidak mengalami diare lebih tinggi
(37,9\%) dibandingkan dengan responden yang memiliki jamban tetapi tidak memenuhi kriteria jamban sehat $(10,5 \%)$ dan responden yang tidak memiliki jamban $(0,0 \%)$.

\section{DAFTAR PUSTAKA}

1. WHO, 2013. Diarrhoeal disease. [Online] Available at: http://www.who.int/mediacentre/factsheets/fs330/en/ [Diakses 18 May 2014].

2. Ani LS, Suwiyoga K. Traveler's Diarrhea Risk Factors on Foreign Tourists in Denpasar Bali-Indonesia May and August 2013

3. KEMENKES RI, 2013. Riset Kesehatan Dasar (RISKESDAS) 2013, Jakarta: Badan Penelitian dan Pengembangan Kesehatan Kementrian Kesehatan Republik Indonesia.

4. DINKES Provinsi Bali, 2013. Profil Kesehatan Provinsi Bali Tahun 2012, Denpasar: Dinas Kesehatan Provinsi Bali.

5. DINKES Pemkab Karangasem, 2013. Laporan Tahunan UP Puskesmas Manggis I Tahun 2013, Karangasem: UPT. Puskesmas Manggis I.

6. FK UNUD, RSUP Sanglah, 2010. Pedoman Pelayanan Medis Ilmu Kesehatan Anak, RSUP Sanglah, Denpasar 2010. Denpasar: SMF Ilmu Kesehatan Anak.

7. WHO, 2012. Combating Waterbone Disease at the Household Level. Geneva: WHO Press.

8. KEMENKES RI, 2012. Profil Kesehatan Indonesia 2011, Jakarta: Kementerian Kesehatan Republik Indonesia.

9. UNICEF Indonesia, 2012. Air bersih, sanitasi, dan kebersihan. Jakarta: UNICEF Indonesia.

10. Notoatmodjo, S., 2010. Metodologi Penelitian Kesehatan. Jakarta: PT Rineka Cipta.

11. Nuraeni, A., 2012. Hubungan Penerapan PHBS Keluarga dengan Kejadian Diare Balita di Kelurahan Tawangmas Kota Semarang, Depok: Fakultas Ilmu Keperawatan Universitas Indonesia.

12. KEMENKES RI, 2011. Situasi DIARE di Indonesia, Jakarta: Kementerian Kesehatan Republik Indonesia.

13. Tumbelaka, A. R. \& Karyanti, M. R., 2009. Air Susu Ibu dan Pengendalian Infeksi. Jakarta: Balai Penerbit FKUI.

14. Matondang, C., Munasir, Z. \& Kurniati, N., 2009. Aspek Imunologi Air Susu Ibu. Dalam: Buku Ajar AlergiImunologi Anak. Jakarta: Badan Penerbit IDAI, pp. 189-202.

15. Rahmadhani, E. P., Lubis, G. \& Edison, 2013. HUbungan Pemberian ASI Eksklusif dengan Angka Kejadian Diare Akut pada Bayi Usia 0-1 Tahun di Puskesmas Kuranji Kota Padang. Jurnal Kesehatan Andalas, Volume 2 (2), pp. 62-66.

16. Wijayanti, P., 2009. Hubungan Kepadatan Lalat dengan Kejadian Diare Balita yang Bermukim di Sekitar Tempat Pembuangan Akhir Sampah Bantar Gebang. Jakarta: Universitas Indonesia.

17. Suryani, 2009. Cuci Tangan Cara Mudah Cegah Penyakit. Jakarta: s.n.

18. Wulandari, A., 2009. Hubungan antara faktor sosiodemografi dan faktor lingkungan dengan kejadian diare pada balita di desa Blimbing Kecamatan Sambirejo. Surakarta: Universitas Muhammadiyah.

19. DEPKES RI, 2009. Seri Perilaku Hidup Bersih dan Sehat di Rumah Tangga. Jakarta: Departemen Kesehatan Republik Indonesia.

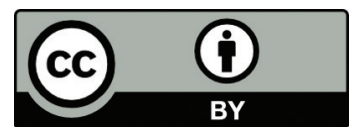

This work is licensed under a Creative Commons Attribution 